\title{
Estimation of vehicle operational fuel consumption
}

\begin{abstract}
A method of a reference fuel consumption calculation for a registered operating conditions has been presented in this work. The operating conditions have been described using specific energy consumption, which takes into account both an influence of external conditions and driver's style of driving. Results of experiments performed on the territory of the city of Gdańsk in normal urban traffic have been presented. The new concept of estimation of vehicle drive system efficiency and related examples have been also included.
\end{abstract}

Key words: operational fuel consumption, vehicle operating conditions, drive system efficiency

\section{Ocena eksploatacyjnego zużycia paliwa samochodów}

\begin{abstract}
W pracy przedstawiono metodę umożliwiająca wyznaczenie referencyjnego zużycia paliwa dla zarejestrowanych warunków eksploatacji. Warunki eksploatacji opisane sq rozkładem energochłonności jednostkowej, która obejmuje zarówno wpływ warunków zewnętrznych, jak również styl jazdy kierowcy. W pracy przedstawiono zestawienie wyników uzyskanych dla przejazdów wykonanych na terenie Gdańska, w regularnym ruchu miejskim. Przedstawiono także koncepcję oceny efektywności energetycznej pojazdów wraz z przykładami.

Słowa kluczowe: eksploatacyjne zużycie paliwa, warunki eksploatacji pojazdu, efektywność układu napędowego
\end{abstract}

\section{Introduction}

Vehicle operational fuel consumption estimation has a measurable significance for both individual users as well as transport and communications companies. Complex analysis of the results may cause reduction of energy (fuel) consumption and toxic compounds emissions in exhaust gases $[3,13$, $14,15,17]$. Such an appraisal enables to: determine optimal drive system control, detect defects in drive system, choose optimal route, choose proper consumables, choose the best power unit (used construction solutions).

One of two following parameters are usually used for operational fuel consumption estimation: exploitation efficiency $\left(\eta_{\exp }[\%]\right)$ or fuel consumption $\left(\mathrm{Q}\left[\mathrm{dm}^{3} / 100 \mathrm{~km}\right]\right)$. Application of the second parameter for vehicle operational fuel consumption estimation is definitely most popular among drivers because it allows them for conducting independent measurements by themselves and results interpretation is easy. Confidence of drivers in those results is also caused by the fact that fuel consumption measurements are carried out in real traffic conditions and they take into account specificity of the style of driving a car by a given driver. Operational fuel consumption estimation carried out by drivers encounters basic difficulties connected with the lack of reliable reference standard for comparison of measured fuel consumption during car usage $[1,2,9,12,16$, $18]$. Therefore it is necessary to identify vehicle operating conditions and ascribe them fuel consumption according to the accepted reference standard.

\section{Influence of operating conditions on fuel consumption}

Vehicle operating conditions will be identified with the use of numerical energy factor called specific energy

\section{Wstęp}

Ocena eksploatacyjnego zużycia paliwa samochodu ma wymierne znaczenie zarówno dla indywidualnych użytkowników, jak również dla firm transportowych i komunikacyjnych. Kompleksowa analiza wyników może się przyczynić do zmniejszenia zużycia energii (paliwa) oraz emisji związków toksycznych w spalinach [3, 13, 14, 15, 17]. Ocena taka umożliwia: wyznaczenie optymalnego sterowania układem napędowym, wykrycie usterek w układzie napędowym, wybór optymalnej drogi przejazdu, dobór właściwych materiałów eksploatacyjnych, wybór najlepszej jednostki napędowej (zastosowanych rozwiązań konstrukcyjnych).

Do oceny eksploatacyjnego zużycia paliwa wykorzystywany jest najczęściej jeden z dwóch parametrów: sprawność eksploatacyjna $\left(\eta_{\exp }[\%]\right)$ lub przebiegowe zużycie paliwa $\left(\mathrm{Q}\left[\mathrm{dm}^{3} / 100 \mathrm{~km}\right]\right)$. Użycie drugiego $\mathrm{z}$ wymienionych parametrów do oceny eksploatacyjnego zużycia paliwa pojazdu cieszy się zdecydowanie większą popularnością wśród kierowców, ponieważ pozwala im prowadzić osobiście niezależne pomiary oraz stwarza niezwykłą łatwość interpretacji wyników. Zaufanie kierowców do takich wyników spowodowane jest również tym, że pomiary przebiegowego zużycia paliwa prowadzone są $\mathrm{w}$ rzeczywistych warunkach ruchu i uwzględniają specyfikę warunków ruchu w określonym mieście lub dzielnicy oraz specyfikę sposobu prowadzenia pojazdu przez danego kierowcę. Ocena eksploatacyjnego zużycia paliwa prowadzona przez kierowców samochodów napotyka jednak na podstawowe trudności związane $\mathrm{z}$ brakiem wiarygodnego wzorca, $\mathrm{z}$ którym pomierzone $\mathrm{w}$ czasie eksploatacji zużycie paliwa można porównać $[1,2,9$, $12,16,18]$. Konieczna jest w związku z tym identyfikacja warunków eksploatacji pojazdu i przypisanie im, według przyjętego modelu, referencyjnego zużycia paliwa. 
consumption $\Phi$, that takes into account both an influence of external conditions and driver's style of driving [10, $15,17]$. The factors mentioned above affect the amount of mechanical energy transmitted to the drive wheels, which is one of parameters constituting energy factor mentioned above. The amount of mechanical energy transmitted to the drive wheels during measurement cycle may result to the same extent from traffic conditions and driver's style of driving a car. Therefore these two factors are treated equally in a proposed method and their impact on vehicle operating conditions were captured in the same numerical energy factor. The value of $\Phi$ parameter for assumed cycle $t_{c}$ duration may be calculated using the following equation [10]:

$$
\Phi=\frac{\mathrm{E}}{\mathrm{L}_{\mathrm{n}} \cdot \mathrm{m}}[\mathrm{J} /(\mathrm{m} \cdot \mathrm{kg})]
$$

where: $\mathrm{E}$ - mechanical energy delivered by drive system to the wheels, $\mathrm{L}_{\mathrm{n}}$ - distance covered by the car in engine propulsion phase, $\mathrm{m}-$ gross vehicle mass.

The place of vehicle operation (traffic intensity) and the style of driving a car may be explicitly described in the proposed method [10] by the probability density function of parameter $\Phi$ :

$$
\mathrm{f}_{\Phi}=\mathrm{f}(\Phi)
$$

This function may be determined by means of periodic registration of basic parameters describing vehicle operating conditions, among others: rotational speed of engine crankshaft and torque (from the model of vehicle drive system - in case there is no a system of this parameter measurement), travelled distance. The following condition must be met for the assumed parameter $\Phi$ change limit:

$$
\int_{\Phi_{\min }}^{\Phi_{\max }} \mathrm{f}_{\Phi} \mathrm{d} \Phi=1
$$

Function (2) may be used both in a continuous and discrete (histogram) form.

Below there are presented results obtained for over 100 drives made on the territory of the city of Gdańsk in normal urban traffic. Measurements of chosen parameters of engine and of test vehicle with spark ignition engine (speed, acceleration, fuel consumption, elevation above sea level, etc.) with the use of special sensors were made. Style of driving a car was based on a style of driving of randomly chosen vehicle [11]. A chosen vehicle was tracked by a test vehicle in order to limit an influence of individual style of driving of a test driver on test results. Figure 1 shows the influence of specific energy consumption during executed drive $(\Phi)$ on fuel consumption in propulsion phase $\left(\mathrm{Q}_{\mathrm{n}}\right)$.

Results presented in Fig. 1 allow to state that there is a close correlation between fuel consumption in propulsion phase $\left(\mathrm{Q}_{\mathrm{n}}\right)$ and specific energy consumption $(\Phi)$. The above relation may form an approximated linear function in a form of $[8,9]$ :

\section{Wpływ warunków eksploatacji na zużycie paliwa}

Warunki eksploatacji pojazdu identyfikowane będą za pomocą liczbowego wskaźnika energetycznego zwanego energochłonnością jednostkową $\Phi$, który obejmuje zarówno wpływ warunków zewnętrznych, jak również styl jazdy kierowcy $[10,15,17]$. Wymienione czynniki wpływają na ilość energii mechanicznej przekazywanej kołom napędowym, która jest jednym $\mathrm{z}$ parametrów tworzących wspomniany wskaźnik energetyczny. Ilość energii mechanicznej przekazywana kołom napędowym w czasie cyklu pomiarowego może wynikać w równym stopniu z zaistniałych warunków ruchu pojazdów, co ze stylu jazdy kierowcy. Z tego powodu, w zaproponowanej metodzie wspomniane czynniki są traktowane jako równoważne, a ich oddziaływania na warunki eksploatacji pojazdu zostały ujęte w tym samym liczbowym wskaźniku energetycznym. Wartość parametru $\Phi$ dla założonego czasu trwania cyklu $\mathrm{t}_{\mathrm{c}}$, można obliczyć korzystając $\mathrm{z}$ równania [10] (1),

gdzie: E - energia mechaniczna dostarczona przez układ przeniesienia napędu do kół, $\mathrm{L}_{\mathrm{n}}$ - droga pokonana przez pojazd w fazie napędzania przez silnik, $\mathrm{m}$ - masa całkowita pojazdu.

Miejsce eksploatacji (intensywność ruchu) oraz sposób prowadzenia pojazdu mogą być w zaproponowanej metodzie [10] jednoznacznie opisane za pomocą funkcji gęstości rozkładu parametru $\Phi$ - wzór (2).

Funkcja ta może zostać wyznaczona na drodze okresowej rejestracji podstawowych parametrów opisujących warunki eksploatacji pojazdu, między innymi: prędkości obrotowej wału korbowego silnika i momentu obrotowego (z modelu układu napędowego pojazdu - w przypadku braku systemu pomiaru tego parametru), przejechanej drogi. Dla przyjętych granic zmian parametru $\Phi$ spełniony musi być ponadto warunek (3).

Funkcja (2) może być używana zarówno w postaci ciągłej, jak również dyskretnej (histogramu).

Poniżej przedstawiono zestawienie wyników uzyskanych dla przeszło 100 przejazdów wykonanych na terenie Gdańska, w regularnym ruchu miejskim. Wykonane zostały pomiary wybranych parametrów pracy silnika i pojazdu

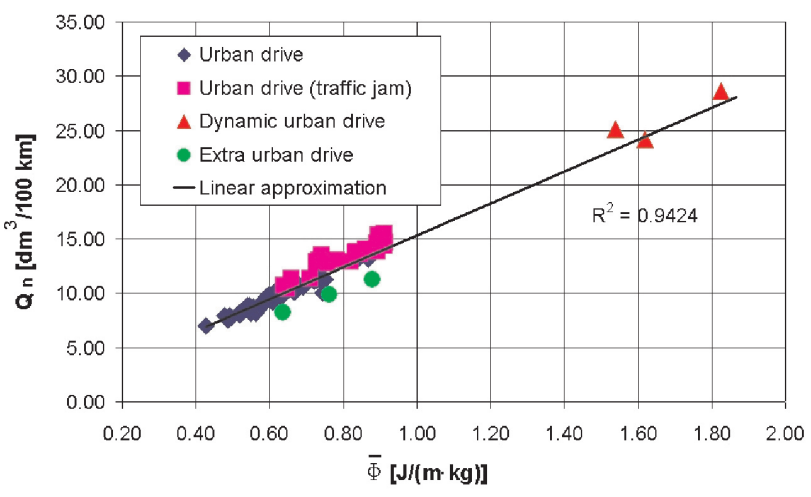

Fig. 1. Influence of specific energy consumption $(\Phi)$ on fuel consumption in propulsion phase $\left(Q_{n}\right)$

Rys. 1. Wpływ energochłonności jednostkowej (Ф) na przebiegowe zużycie paliwa $w$ fazie napędowej $\left(Q_{n}\right)$ 


$$
\mathrm{Q}_{\mathrm{n}}=\mathrm{k}_{1} \cdot \Phi+\mathrm{k}_{0}
$$

where: $Q_{n}\left[\mathrm{dm}^{3} / 100 \mathrm{~km}\right]$ - fuel consumption in propulsion phase (excluding fuel consumed by the engine at idle speed), $\mathrm{k}_{1}, \mathrm{k}_{0}$ - approximating function coefficients.

The relation obtained by linear approximation may be used with great accuracy (for data shown in Figure 1 $\mathrm{R}^{2}=0.942$ ) for forecasting fuel consumption during vehicle operation in urban conditions. In extra-urban conditions, on account of extremely favourable conditions of engine running, the results obtained in case of relation presented in Figure 1 may be burdened with certain systematic error (small variable load and favourable, from the point of view of efficiency, position of engine operation point $[6,7,12,17])$.

Characteristics described by equation (4) may be determined in a simplified way with a use of one drive in conditions of normal vehicle operation. Figures 2 and 3 show the results of such trials with a description of parameters of functions determined for two test vehicles marked vehicle 1 and vehicle 2 , the chosen parameters of which are presented in Table 1.

(prędkość, przyspieszenie, zużycie paliwa, położenie nad poziomem morza itd.) pojazdu testowego z silnikiem o zapłonie iskrowym, z użyciem odpowiednich czujników. Styl jazdy kierowcy podporządkowany był stylowi prowadzenia losowo wybranego pojazdu [11]. Wybrany pojazd był ,śledzony" przez pojazd testowy w celu ograniczenia wpływu indywidualnego stylu jazdy kierowcy testowego na wyniki próby. Na rysunku 1 przedstawiono wpływ energochłonności jednostkowej odbytego przejazdu $(\Phi)$ na przebiegowe zużycie paliwa w fazie napędowej $\left(\mathrm{Q}_{\mathrm{n}}\right)$.

Wyniki przedstawione na rys. 1 pozwalają stwierdzić, iż istnieje ścisła korelacja między przebiegowym zużyciem paliwa $\mathrm{w}$ fazie napędowej $\left(\mathrm{Q}_{\mathrm{n}}\right)$ a energochłonnością jednostkową $(\Phi)$. Zależność powyższa może być aproksymowana funkcją liniową w postaci $[8,9](4)$,

gdzie: $Q_{n}\left[\mathrm{dm}^{3} / 100 \mathrm{~km}\right]$ - przebiegowe zużycie paliwa $\mathrm{w}$ fazie napędowej ( $\mathrm{z}$ wyłączeniem paliwa zużywanego przez silnik na biegu jałowym), $\mathrm{k}_{1}, \mathrm{k}_{0}$ - współczynniki funkcji aproksymującej.

Uzyskana na drodze liniowej aproksymacji zależność może być stosowana przy zachowaniu dużej dokładności (dla danych na rys. $1 \mathrm{R}^{2}=0,942$ )

Table 1. Parameters of vehicles used in tests Tabela 1. Parametry pojazdów wykorzystanych $w$ badaniach

\begin{tabular}{|c|c|c|c|}
\hline \multirow{2}{*}{\multicolumn{2}{|c|}{ Name of parameter/nazwa parametru }} & \multicolumn{2}{|c|}{ Value of parameter/wartość parametru } \\
\hline & & vehicle $1 /$ pojazd 1 & vehicle $2 /$ pojazd 2 \\
\hline Vehicle mass/masa samochodu & $\mathrm{m}[\mathrm{kg}]$ & 1243 & 1343 \\
\hline Year of production/rok produkcji & & 2003 & 2003 \\
\hline $\begin{array}{l}\text { Wheel dynamic radius/promien dynamiczny } \\
\text { koła }\end{array}$ & $\mathrm{r}_{\mathrm{d}}[\mathrm{mm}]$ & 265 & 297 \\
\hline $\begin{array}{l}\text { Final drive ratio/przełożenie przektadni } \\
\text { głównej }\end{array}$ & $\mathrm{i}_{\mathrm{g}}$ & 4.12 & 4.44 \\
\hline 1st gear ratio/przełożenie na biegu I & $\mathrm{i}_{\mathrm{bI}}$ & 3.46 & 3.33 \\
\hline $\begin{array}{l}\text { Air resistance coefficient/wsp. oporu } \\
\text { powietrza }\end{array}$ & $\mathrm{C}_{\mathrm{x}}$ & 0.32 & 0.34 \\
\hline $\begin{array}{l}\text { Rolling resistance coef. (smooth asphalt)/ } \\
\text { wsp. oporu toczenia (gladki asfalt) }\end{array}$ & $\mathrm{f}_{\text {to }}$ & 0.012 & 0.012 \\
\hline $\begin{array}{l}\text { Drive system efficiency/sprawność } u k t \text {. } \\
\text { przen. napędu }\end{array}$ & $\eta_{\text {UPN }}$ & 0.92 & 0.94 \\
\hline
\end{tabular}
do prognozowania zużycia paliwa przy eksploatacji pojazdu w warunkach miejskich. W warunkach pozamiejskich, ze względu na wyjątkowo korzystne warunki pracy silnika, wyniki uzyskane z zależności przedstawionej na rys. 1 mogą być obarczone pewnym systematycznym błędem (mała zmienność obciążenia oraz korzystne, $\mathrm{z}$ punktu widzenia sprawności, położenie punktu pracy silnika $[6,7,12,17])$.

Charakterystykę opisaną równaniem (4) można wyznaczyć w uproszczony sposób wykorzystując do tego celu

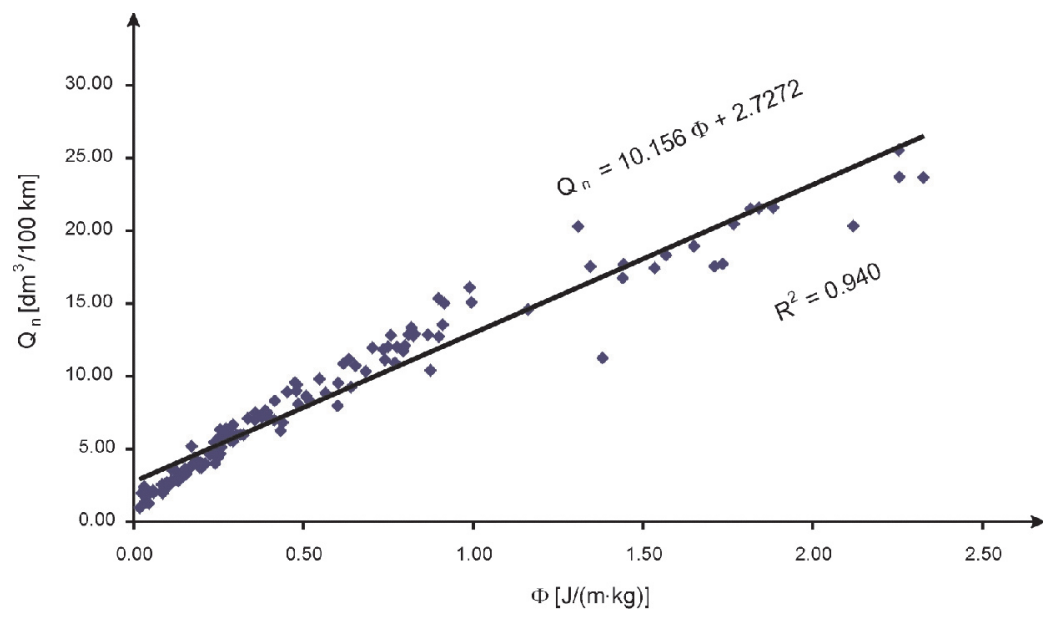

Fig. 2. Simplified procedure of determining relation (4) for vehicle 1 Rys. 2. Uproszczona procedura wyznaczania zależności (4) dla pojazdu 1 jeden przejazd w warunkach normalnej eksploatacji pojazdu. Na rys. 2 i 3 przedstawiono wyniki takich prób z opisem parametrów funkcji wyznaczonych dla dwóch pojazdów testowych o oznaczeniach pojazd 1 i pojazd 2, których wybrane parametry przedstawiono w tabeli 1.

Zależność (4), którą wyznaczono w czasie powyższych eksperymentów (rys. 2 i 3 ) można traktować jako funkcyjny lub dwuparametrowy (współczynniki $\mathrm{k}_{1} \mathrm{i} \mathrm{k}_{0}$ ) opis efektywności pracy układu napędowego. W odróżnieniu od dotychczas używanego przebiegowego zużycia paliwa $\mathrm{Q}\left[\mathrm{dm}^{3} / 100 \mathrm{~km}\right.$ ] opis za pomoca funkcji (4) obejmuje pełen zakres pracy układu napędowego. Nie następuje tutaj także niejed- 


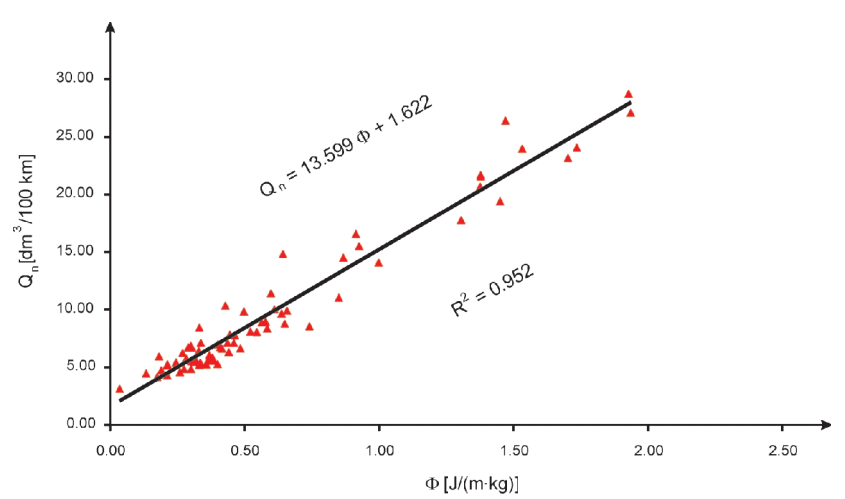

Fig. 3. Simplified procedure of determining relation (4) for vehicle 2 Rys. 3. Uproszczona procedura wyznaczania zależności (4) dla pojazdu 2

The relation (4), determined during the above mentioned experiments (Fig. 2 and 3 ) may be treated as functional or two-parameter (coefficient $\mathrm{k}_{1}$ and $\mathrm{k}_{0}$ ) description of drive system efficiency. Unlike fuel consumption Q [ $\left.\mathrm{dm}^{3} / 100 \mathrm{~km}\right]$ used so far, description with the use of function (4), includes full range of work of drive system. Moreover there is no ambiguous classification of working conditions divided into urban cycle and extra-urban cycle. When comparing energy efficiency of two vehicles, relative position of these vehicles function (4) should be taken into account. Approximating function of a vehicle characterized by more efficient drive system will have lower position (4) $[8,9]$. Figure 4 shows relative to each other positions of approximating straight lines (4) obtained during road testing of vehicles 1 and 2.

Examination results show that the vehicle 1 has drive system that is running more efficiently in traffic conditions corresponding to higher values $\Phi(1)$ that is of more dynamic driving.

\section{Reference fuel consumption}

With the use of relation (4) identified by an experimental method it is possible to calculate reference fuel consumption for identified operating conditions (for the same function of parameter $\Phi$ distribution - in discrete form it will be a histogram) [8]:

$$
\overline{\mathrm{Q}}=\frac{1}{\mathrm{~L}}\left\{\mathrm{~L}_{\mathrm{n}} \int_{\Phi_{\min }}^{\Phi_{\max }}\left[\mathrm{f}_{\Phi}\left(\mathrm{k}_{1} \cdot \Phi+\mathrm{k}_{0}\right)\right] \mathrm{d} \Phi+\vartheta_{\text {b.j. }}+\vartheta_{\mathrm{h}}\right\}
$$

where: $\Phi_{\min }, \Phi_{\max }-$ parameter $\Phi$ change limit, $\mathrm{f}_{\Phi}-$ function of parameter $\Phi$ density distribution characterizing vehicle operating conditions, $\vartheta_{\mathrm{b.j},}\left[\mathrm{dm}^{3}\right]$ - fuel consumed during engine work at idle speed, $\vartheta_{\mathrm{h}}\left[\mathrm{dm}^{3}\right]$ - fuel consumed during braking (during engine braking: $\vartheta_{\mathrm{h}} \rightarrow 0$ ), L [m] - total distance covered by the vehicle, $L_{n}[\mathrm{~m}]$ - distance covered by the vehicle in engine propulsion phase.

Fuel consumed during engine work at idle speed may be calculated on the basis of the following relation:

$$
\vartheta_{b . j .}=\frac{t_{b . j .}}{t_{c}} \cdot t_{c} \cdot G_{b . j .}
$$

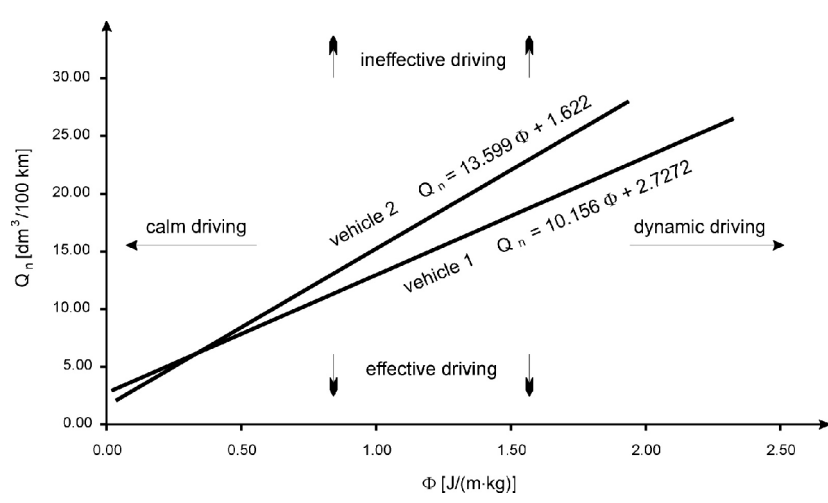

Fig. 4. Relative positions of approximating straight lines (4) obtained during road testing of vehicles 1 and 2

Rys. 4. Wzajemne położenie prostych aproksymacyjnych (4) uzyskanych w czasie badań drogowych pojazdów 1 i 2

noznaczna klasyfikacja warunków pracy na ruch miejski i pozamiejski. Porównując efektywność energetyczną dwóch pojazdów należy wziąć pod uwagę względne położenie funkcji (4) tych pojazdów. Pojazd o bardziej efektywnym układzie napędowym będzie posiadał niżej położoną funkcję aproksymującą (4) $[8,9]$. Na rysunku 4 pokazane zostało wzajemne położenie prostych aproksymacyjnych (4) uzyskanych w czasie badań drogowych pojazdów $\mathrm{nr} 1$ i nr 2 .

Wyniki badań pokazują, iż pojazd 1 posiada układ napędowy, który pracuje bardziej efektywnie przy warunkach ruchu odpowiadających większym wartościom $\Phi(1)$, czyli bardziej dynamicznej jeździe.

\section{Referencyjne zużycie paliwa}

Wykorzystując zidentyfikowaną na drodze eksperymentalnej zależność (4) można obliczyć referencyjne zużycie paliwa dla rozpoznanych warunków eksploatacji (dla tej samej funkcji rozkładu parametru $\Phi-$ w postaci dyskretnej będzie to histogram) [8] (5),

gdzie: $\Phi_{\text {min }}, \Phi_{\max }-$ granice zmian parametru $\Phi, \mathrm{f}_{\Phi}-$ funkcja gęstości rozkładu parametru $\Phi$ charakteryzująca warunki eksploatacji pojazdu, $\vartheta_{\mathrm{b} . \mathrm{j}}\left[\mathrm{dm}^{3}\right]$ - paliwo zużyte podczas pracy silnika na biegu jałowym, $\vartheta_{\mathrm{h}}\left[\mathrm{dm}^{3}\right]$ - paliwo zużyte podczas hamowania ( $\mathrm{w}$ czasie hamowania silnikiem: $\vartheta_{\mathrm{h}} \rightarrow 0$ ), L [m] - całkowita droga przebyta przez pojazd, $\mathrm{L}_{\mathrm{n}}[\mathrm{m}]$ - droga przebyta przez pojazd gdy był on napędzany przez silnik.

Paliwo zużyte podczas pracy silnika na biegu jałowym może być obliczone według zależności (6),

gdzie: $\mathrm{G}_{\mathrm{b} . \mathrm{j}}-$ czasowe zużycie paliwa przy pracy silnika na biegu jałowym, $t_{c}$ - całkowity czas przejazdu, $t_{b . j}$ - czas pracy silnika na biegu jałowym.

Metoda (5) jest dedykowana do obliczeń referencyjnego zużycia paliwa w warunkach złożonego ruchu, występującego w miastach. Zgodnie z wynikami zamieszczonymi na rys. 1 użycie metody (5) przy wyższych średnich prędkościach jazdy, np. $100 \mathrm{~km} / \mathrm{h}$, może być obarczone dodatkowym błędem. Poprzez obliczenie referencyjnego zużycia paliwa (5) dla zarejestrowanych warunków eksploatacji za pomocą funkcji (2) możliwe jest porównanie eksploatacyjnego zużycia paliwa z referencyjnym dla rzeczywistych warunków 
where: $G_{b . j .}-$ fuel consumed per time during engine work at idle speed, $t_{c}$ - total drive time, $t_{b . j .}$ - duration of engine work at idle speed.

Method (5) is dedicated for the calculation of the reference fuel in a complex traffic conditions, which occurs in cities. According to the results presented in Figure 1 using the method (5) with higher average driving speeds, e.g. $100 \mathrm{~km} / \mathrm{h}$, may be burdened with additional error. Calculating of reference fuel consumption (5) for registered operating conditions with the use of function (2) enables to compare operational fuel consumption with reference fuel consumption for real operating conditions. Appearance of a significant difference between operational and reference fuel consumption indicates a defect in drive system of a vehicle or practicing grossly improper driving techniques like driving on 2 nd gear at a constant speed of $70 \mathrm{~km} / \mathrm{h}$. This method does not allow for explicit identification of the reasons of existing difference whereas a driver may in a real time ascertain whether an increase in registered fuel consumption is justified by deterioration of operating conditions (e.g. dynamic style of driving).

\section{Comparison of vehicles energy efficiency}

Comparison of vehicles energy efficiency may generally be conducted with the use of $\mathrm{k} 1$ and $\mathrm{k} 0$ coefficients that determine relative to each other positions of approximating straight lines (4) created for vehicles comparison. A vehicle with more efficient drive system will have lower approximating function (4). In case approximating straight lines (4) are crossing (Fig. 4) an unambiguous determination which vehicle has more efficient drive system is impossible. In such a case density function of parameter $\Phi$ (2) distribution should be included in the analysis. It should be emphasized that the comparison of energy efficiency makes sense for vehicles in the same class and of similar mass.

Below there are examples of comparison of reference fuel consumption (5) of two vehicles (Table 1) calculated for the traffic conditions registered with the use of a test vehicle on the territory of the city of Gdańsk. Travel routes chosen for the needs of the analysis located in the city centre and in its outskirts are shown in Fig. 5.

Figure 6 presents vehicle speed run for route No. 1 running across Gdańsk outskirts together with a given average speed $(\bar{V})$ and share of engine working time at idle speed in comparison with the total test time $\left(t_{b j} / t_{c}\right)$. For identification of vehicle operation conditions histogram of parameter $\Phi$ distribution during this drive was used. This distribution was described by the parameters: average value and standard deviation $\bar{\Phi}$, the values of which are shown in Figure 7. Additionally the Figure shows a value of the share of travelled distance in engine propulsion phase in comparison to the total distance $\left(\mathrm{L}_{\mathrm{n}} / \mathrm{L}\right)$. eksploatacji. Powstanie znaczącej różnicy między eksploatacyjnym a referencyjnym zużyciem paliwa wskazuje na powstanie usterki w układzie napędowym pojazdu lub stosowaniem rażąco niewłaściwych technik jazdy samochodem, np. jazda z wybranym II biegiem w przekładni wybieralnej przy stałej prędkości $70 \mathrm{~km} / \mathrm{h}$. Metoda nie pozwala jednoznacznie zidentyfikować przyczyn powstałej różnicy. Kierowca pojazdu może natomiast na bieżąco stwierdzać, czy wzrost rejestrowanego zużycia paliwa jest uzasadniony pogarszającymi się warunkami eksploatacji (np. dynamicznym stylem jazdy).

\section{Porównywanie efektywności energetycznej pojazdów}

Porównanie efektywności energetycznej pojazdów w ogólnym wypadku można przeprowadzić za pomocą współczynników $\mathrm{k}_{1}$ i $\mathrm{k}_{0}$ określających wzajemne położenie prostych aproksymacyjnych (4) utworzonych dla porównywanych pojazdów. Pojazd o bardziej efektywnym układzie napędowym będzie posiadał niżej położoną funkcję aproksymującą (4). W przypadku, gdy proste aproksymacyjne (4) przecinają się (rys. 4) jednoznaczne określenie, który z pojazdów posiada bardziej efektywny układ napędowy nie jest możliwe. W takim wypadku należy do analizy włączyć funkcję gęstości rozkładu parametru $\Phi$ (2). Należy podkreślić, że porównanie efektywności energetycznej ma sens w odniesieniu do pojazdów o tej samej klasie i o zbliżonej masie.

Poniżej zamieszczono przykłady porównania referencyjnego zużycia paliwa (5) dwóch pojazdów (tab. 1) obliczonego dla warunków ruchu zarejestrowanych przy użyciu pojazdu testowego na terenie miasta Gdańsk. Trasy przejazdu wybrane do analizy położone w centrum oraz na przedmieściach Gdańska zostały pokazane na rys. 5.

Na rysunku 6 przedstawiony został przebieg prędkości pojazdu dla trasy nr 1 przebiegającej przez przedmieścia Gdańska wraz z podaną prędkością średnią $(\bar{V})$ oraz

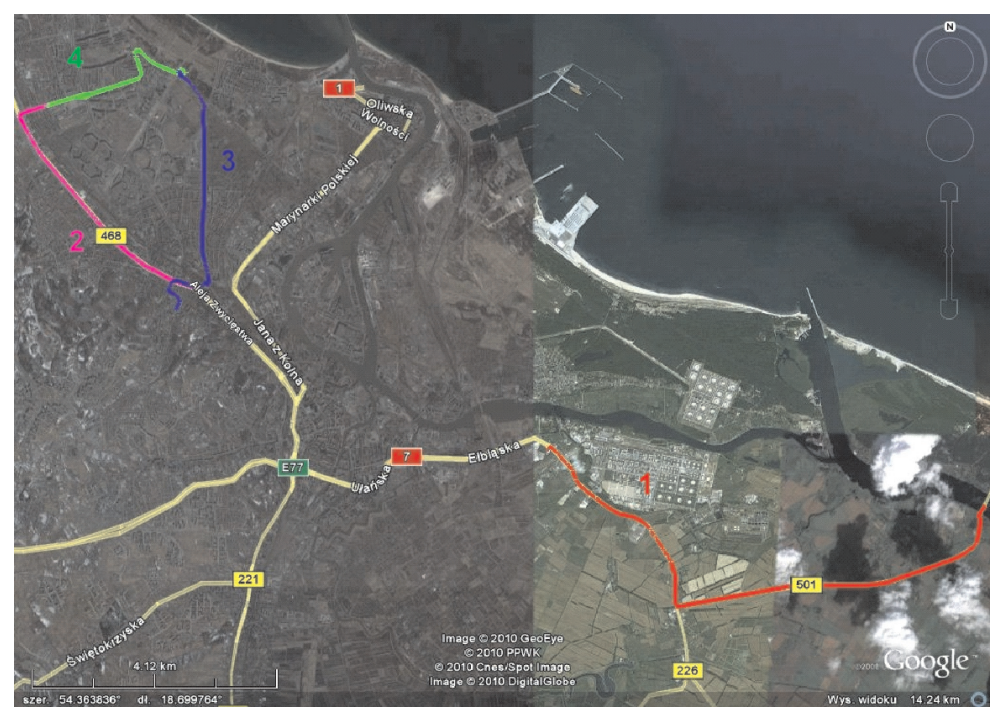

Fig. 5. Travel routes chosen for the analysis of vehicle energy efficiency Rys. 5. Trasy przejazdu wybrane do analizy efektywności energetycznej pojazdów 


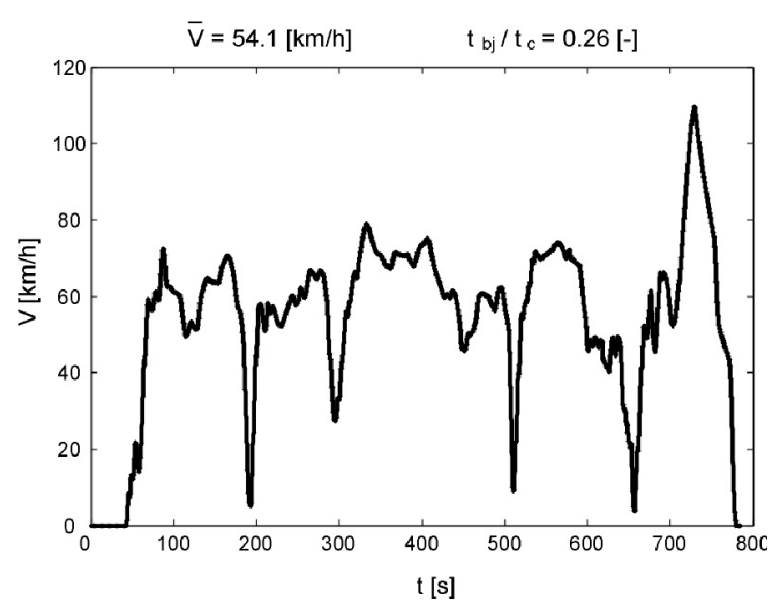

Fig. 6. Vehicle speed run (route No. 1)

Rys. 6. Przebieg prędkości pojazdu (trasa nr 1)

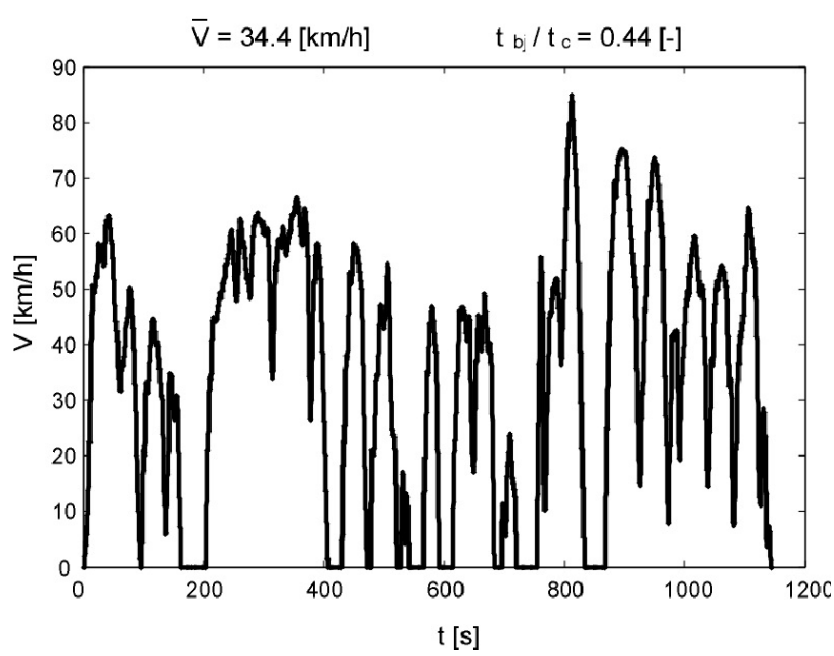

Fig. 8. Vehicle speed run (route No. 2) Rys. 8. Przebieg prędkości pojazdu (trasa nr 2)

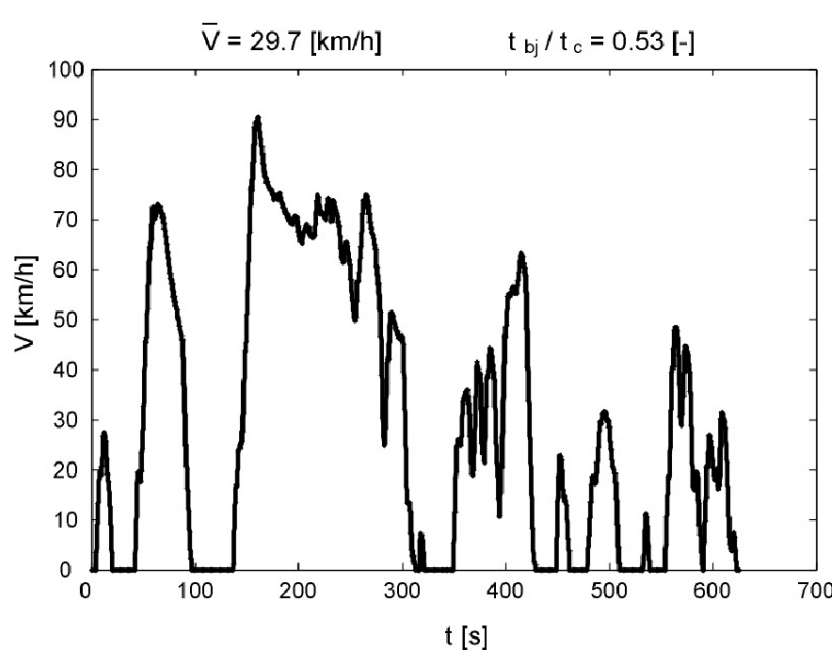

Fig. 10. Vehicle speed run (route No. 3) Rys. 10. Przebieg prędkości pojazdu (trasa nr 3)

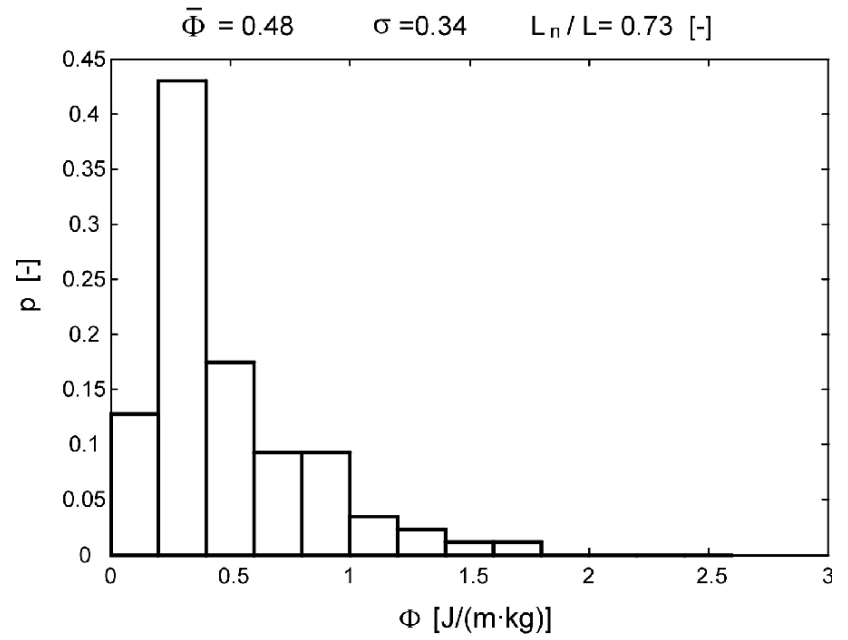

Fig. 7. Histogram of parameter $\Phi$ distribution (route No. 1) Rys. 7. Histogram rozkładu par. $\Phi$ (trasa $\mathrm{nr}$ 1)

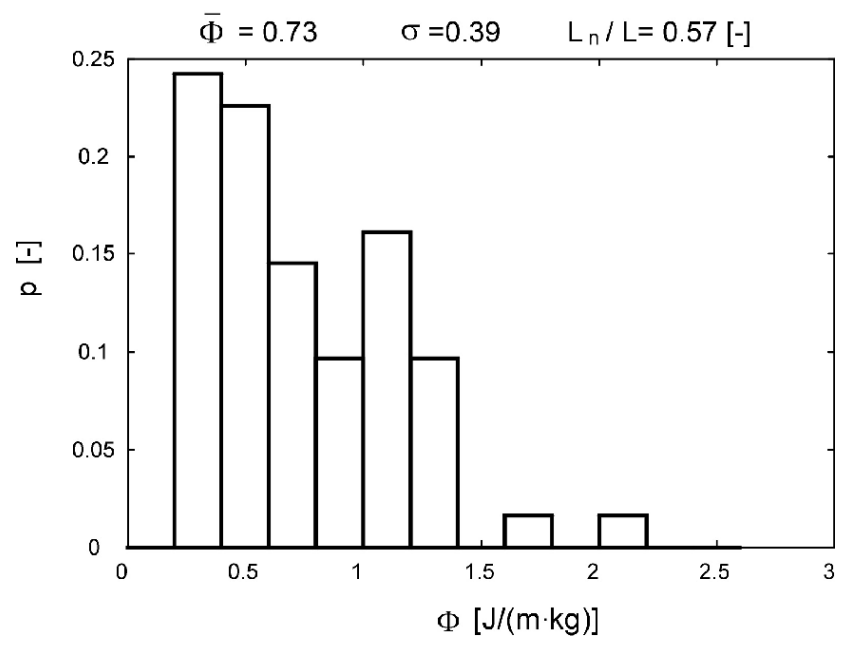

Fig. 9. Histogram of parameter $\Phi$ distribution (route No. 2) Rys. 9. Histogram rozktadu par. $\Phi$ (trasa $n r$ 2)

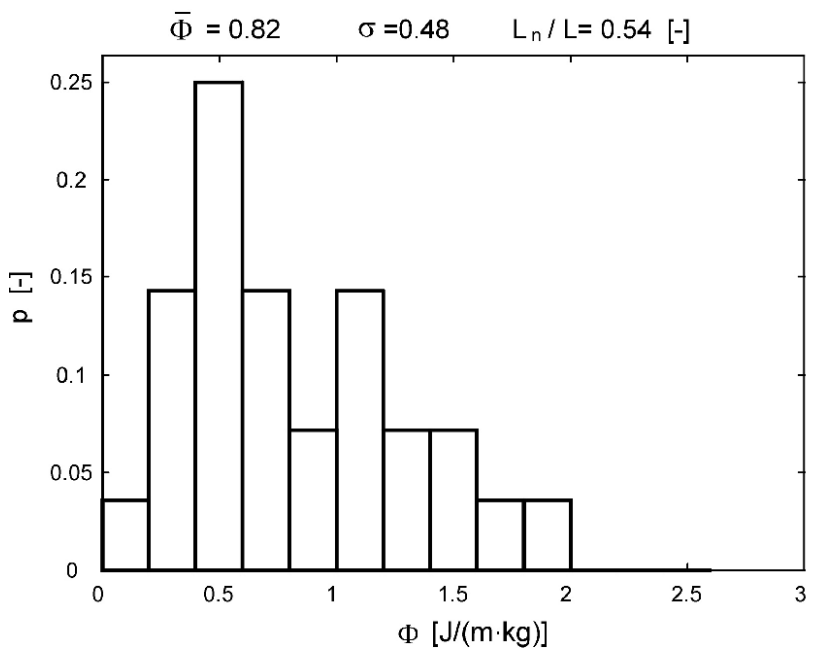

Fig. 11. Histogram of parameter $\Phi$ distribution (route No. 3) Rys. 11. Histogram rozktadu par. $\Phi($ trasa nr 3) 


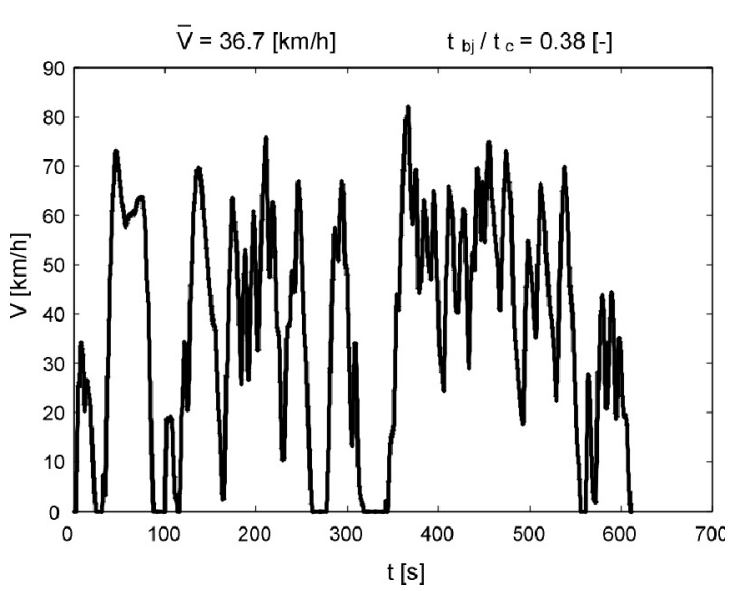

Fig. 12. Vehicle speed run (route No. 4) Rys. 12. Przebieg prędkości pojazdu (trasa $n r$ 4)

Figures 8 and 9 show results of a drive along route No. 2 across the city center along Grunwaldzka street (main threelane line of communication in Gdańsk) and Kołobrzeska street. Figures 10 and 11 show results of a drive along route No. 3 across the city center along Czarny Dwór, Hallera, Do Studzienki streets. Figures 12 and 13 show results of a drive along route No. 4 across the city center along Czarny Dwór, Kołobrzeska streets. The drive was executed with dynamic style of driving and frequent stops resulting from with impediments to traffic.

Generally, route No. 1 runs on roads with low traffic density, while routes 2, 3, 4 with high traffic density. The results of reference fuel consumption calculations (5) of vehicles 1 and 2 for operation conditions met on four chosen routes (Fig. 6-13), described by function $\mathrm{f}_{\Phi}(2)$ and parameters: $\left(\mathrm{L}_{\mathrm{n}} / \mathrm{L}\right),\left(\mathrm{t}_{\mathrm{bj}} / \mathrm{t}_{\mathrm{c}}\right), \mathrm{L}, \mathrm{t}_{\mathrm{c}}$, are presented in Table 2 .

Comparison of reference fuel consumption for operation conditions met on chosen routes shows that more economical is vehicle 1 , which will consume potentially less fuel in all analyzed cases. Moreover, in case of deteriorating traffic conditions (rise of $\bar{\Phi}$ ) relative difference of fuel consumption is steadily growing. In case of the lightest operation conditions (route No. 1) this difference is $10 \%$, and in case of the most difficult operation conditions (route No. 4) this difference reaches $26 \%$. However, this comparison was made with various vehicle mass (vehicle 2 is heavier by $8 \%$ than vehicle 1 ). Used mass corresponded to the state of vehicles during calibration of their characteristics (4) in road conditions.

However, measurable appraisal of vehicle energy efficiency should consist in comparison of reference fuel consumption for the same operation conditions described by function $\mathrm{f}_{\Phi}(2)$ and parameters: $\left(\mathrm{L}_{\mathrm{n}} / \mathrm{L}\right),\left(\mathrm{t}_{\mathrm{bj}} / \mathrm{t}_{\mathrm{c}}\right), \mathrm{L}, \mathrm{t}_{\mathrm{c}}$ and for the same vehicle mass. Evaluation of fuel consumption for such conditions requires introduction of correction into relation (4) that takes into account an influence of present vehicle mass (other than in the moment of relation (4) identification for fuel consumption). Taking into account that relation (4) was created at constant vehicle mass $\mathrm{m}_{0}$ - this formula may have the following form:

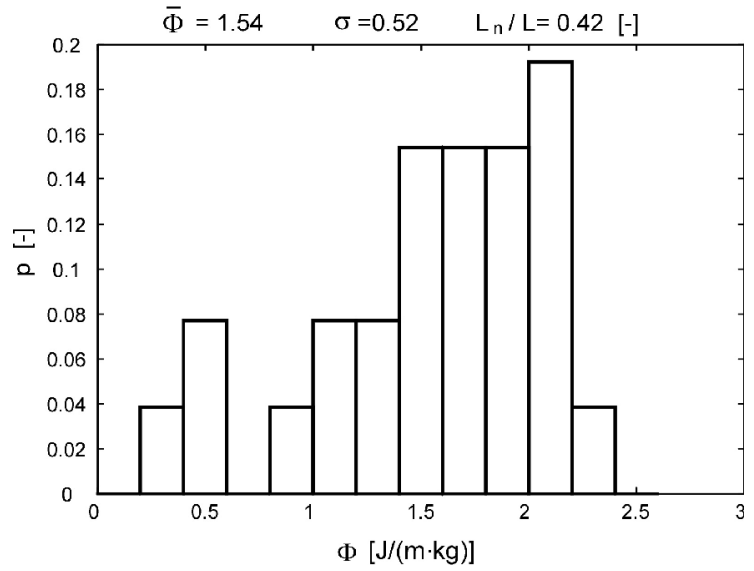

Fig. 13. Histogram of parameter $\Phi$ distribution (route No. 4) Rys. 13. Histogram rozkładu par. $\Phi$ (trasa $\mathrm{nr} 4)$

udziałem czasu pracy silnika na biegu jałowym w stosunku do całkowitego czasu próby $\left(\mathrm{t}_{\mathrm{bj}} / \mathrm{t}_{\mathrm{c}}\right)$. Do identyfikacji warunków eksploatacji pojazdu wykorzystany został natomiast histogram rozkładu parametru $\Phi$ w czasie tego przejazdu. Rozkład ten został opisany parametrami: wartość średnia $(\bar{\Phi})$ oraz odchylenie standardowe $(\sigma)$, których wartości widoczne są na rysunku 7. Dodatkowo na rysunku podano także wartość udziału drogi przejechanej w fazie napędzania przez silnik w stosunku do całkowitej drogi $\left(\mathrm{L}_{\mathrm{n}} / \mathrm{L}\right)$.

Na rysunkach 8 i 9 przedstawione zostały wyniki przejazdu trasą nr 2 przez centrum miasta ul. Grunwaldzką (główna trzypasmowa arteria komunikacyjna Gdańska) oraz ul. Kołobrzeską. Na rysunkach 10 i 11 przedstawione zostały wyniki przejazdu trasą nr 3 przez centrum miasta, ulicami: Czarny Dwór, Hallera, Do Studzienki. Na rysunkach 12 i 13 przedstawione zostały wyniki przejazdu trasą nr 4 przez centrum miasta, ulicami: Czarny Dwór, Kołobrzeska. Przejazd realizowany był przy dynamicznym stylu jazdy kierowcy oraz częstych zatrzymaniach wynikających z utrudnień w ruchu.

Generalnie trasa nr 1 przebiega po drogach o małej gęstości ruchu, natomiast trasy 2, 3, 4 po drogach o dużej gęstości ruchu. Wyniki obliczeń referencyjnego zużycia paliwa (5) pojazdów 1 i 2 dla warunków eksploatacji spotykanych na czterech wybranych trasach (rys. 6-13), opisanych funkcją $\mathrm{f}_{\Phi}(2)$ i parametrami: $\left(\mathrm{L}_{\mathrm{n}} / \mathrm{L}\right),\left(\mathrm{t}_{\mathrm{bj}} / \mathrm{t}_{\mathrm{c}}\right), \mathrm{L}, \mathrm{t}_{\mathrm{c}}$, zamieszczono $\mathrm{w}$ tabeli 2 .

Z porównania referencyjnego zużycia paliwa dla warunków eksploatacji spotykanych na wybranych trasach wynika, że bardziej ekonomicznym jest pojazd 1, który potencjalnie będzie zużywał mniej paliwa we wszystkich analizowanych przypadkach. Ponadto, przy pogarszaniu warunków ruchu (wzrost $\bar{\Phi}$ ) względna różnica zużycia paliwa sukcesywnie rośnie. Przy najlżejszych warunkach eksploatacji (trasa nr 1) różnica ta wynosi $10 \%$, a przy najtrudniejszych warunkach eksploatacji (trasa nr 4) różnica ta dochodzi do 26\%. Porównanie to zostało jednak przeprowadzone przy różnych masach pojazdów (pojazd 2 jest cięższy o $8 \%$ od pojazdu 1). Użyte masy odpowiadały stanowi pojazdów w czasie kalibracji ich charakterystyk (4) w warunkach drogowych. 
Table 2. Comparison of reference fuel consumption of tested vehicles of various mass during operation on chosen routes

Tabela 2. Porównanie referencyjnego zużycia paliwa pojazdów testowych o różnych masach przy eksploatacji na wybranych trasach

\begin{tabular}{|c|c|c|c|c|c|c|c|c|c|}
\hline \multirow{3}{*}{$\begin{array}{c}\text { Route No./ } \\
\text { nr trasy }\end{array}$} & \multirow{3}{*}{$\begin{array}{l}\text { Location/ } \\
\text { lokalizacja }\end{array}$} & \multirow{3}{*}{$\begin{array}{c}\bar{\Phi} \\
{[\mathrm{J} /(\mathrm{m} \cdot \mathrm{kg})]}\end{array}$} & \multirow{3}{*}{$\mathrm{L}_{\mathrm{n}} / \mathrm{L}$} & \multirow{3}{*}{$\mathrm{t}_{\mathrm{bj}} / \mathrm{t}_{\mathrm{c}}$} & \multirow{3}{*}{$\mathrm{L}[\mathrm{m}]$} & \multirow{3}{*}{$\mathrm{t}_{\mathrm{c}}[\mathrm{s}]$} & \multicolumn{2}{|c|}{$\overline{\mathrm{Q}}\left[\mathrm{dm}^{3} / 100 \mathrm{~km}\right]$} & \multirow{2}{*}{$\frac{\overline{\mathrm{Q}_{2}}-\overline{\mathrm{Q}}_{1}}{\overline{\mathrm{Q}}_{1}}$} \\
\hline & & & & & & & $\begin{array}{l}\text { vehicle 1/ } \\
\text { pojazd } 1\end{array}$ & $\begin{array}{l}\text { vehicle } 2 / \\
\text { pojazd } 2\end{array}$ & \\
\hline & & & & & & & $1243 \mathrm{~kg}$ & $1343 \mathrm{~kg}$ & {$[\%]$} \\
\hline 1 & $\begin{array}{l}\text { outskirts/ } \\
\text { przedmieścia }\end{array}$ & 0.48 & 0.73 & 0.26 & 11786 & 784 & 5.77 & 6.35 & 10 \\
\hline 2 & $\begin{array}{l}\text { centre/ } \\
\text { centrum }\end{array}$ & 0.73 & 0.57 & 0.44 & 10937 & 1145 & 6.46 & 7.75 & 20 \\
\hline 3 & $\begin{array}{l}\text { centre/ } \\
\text { centrum }\end{array}$ & 0.82 & 0.54 & 0.53 & 5168 & 625 & 6.95 & 8.54 & 23 \\
\hline 4 & $\begin{array}{l}\text { centre/ } \\
\text { centrum }\end{array}$ & 1.54 & 0.42 & 0.38 & 6245 & 612 & 8.22 & 10.35 & 26 \\
\hline
\end{tabular}

$$
\mathrm{Q}_{\mathrm{n}}=\left.\mathrm{k}_{1}\right|_{\mathrm{m}_{0}} \frac{\mathrm{E}}{\mathrm{L}_{\mathrm{n}} \cdot \mathrm{m}_{0}}+\left.\mathrm{k}_{0}\right|_{\mathrm{m}_{0}}
$$

where: $\mathrm{m}_{0}$ - vehicle mass on the basis of which characteristics (4) was created.

Taking into consideration any vehicle mass $\mathrm{m}$ in relation (7) we get:

$$
\mathrm{Q}_{\mathrm{n}}=\left(\frac{\left.\mathrm{k}_{1}\right|_{\mathrm{m}_{0}}}{\mathrm{~m}_{0}}\right) \frac{\mathrm{E}}{\mathrm{L}_{\mathrm{n}}} \frac{\mathrm{m}}{\mathrm{m}}+\left.\mathrm{k}_{0}\right|_{\mathrm{m}_{0}}
$$

After considering relation (1) we get modified form of relation (4) showing a relationship between operational fuel consumption in propulsion phase with specific energy consumption (1) and current vehicle mass:

$$
\mathrm{Q}_{\mathrm{n}}=\left(\frac{\left.\mathrm{k}_{1}\right|_{\mathrm{m}_{0}}}{\mathrm{~m}_{0}} \mathrm{~m}\right) \Phi+\left.\mathrm{k}_{0}\right|_{\mathrm{m}_{0}}
$$

Verification of formula (9) was made with the use of mathematical model of a vehicle $[4,5,8]$, the chosen parameters of which are included in Table 3 (vehicle 3 ), as well as drives registered in real traffic conditions on the territory
Wymierna ocena efektywności energetycznej pojazdów powinna natomiast polegać na porównaniu referencyjnego zużycia paliwa dla tych samych warunków eksploatacji opisanych funkcją $\mathrm{f}_{\Phi}(2)$ i parametrami: $\left(\mathrm{L}_{\mathrm{n}} / \mathrm{L}\right),\left(\mathrm{t}_{\mathrm{bj}} / \mathrm{t}_{\mathrm{c}}\right), \mathrm{L}, \mathrm{t}_{\mathrm{c}}$ oraz dla tej samej masy pojazdów. Wyznaczenie zużycia paliwa dla takich warunków wymaga wprowadzenia do zależności (4) poprawki uwzględniającej wpływ aktualnej masy pojazdu (innej niż w chwili identyfikacji parametrów zależności (4)) na zużycie paliwa. Uwzględniając, że zależność (4) została utworzona przy stałej masie pojazdu $\mathrm{m}_{0}$, wzór ten można zapisać w postaci (7),

gdzie: $\mathrm{m}_{0}-$ masa pojazdu, przy której została utworzona charakterystyka (4).

Uwzględniając w zależności (7) dowolną masę pojazdu m otrzymujemy (8).

Po uwzględnieniu zależności (1) otrzymujemy zmodyfikowaną formę relacji (4) ujawniającą związek przebiegowego zużycia paliwa w fazie napędowej z energochłonnością jednostkową (1) oraz z aktualną masą pojazdu - wzór (9).

Weryfikację przyjętego modelu (9) przeprowadzono z użyciem matematycznego modelu pojazdu [4, 5, 8], którego wybrane parametry zamieszczono w tabeli 3 (pojazd 3). Weryfikację modelu wykonano z użyciem przejazdów zarejestrowanych $\mathrm{w}$ warunkach rzeczywistego ruchu na terenie miasta Gdańska (profil prędkości oraz zmian wysokości). Weryfikację zdecydowano się przeprowadzić z

\begin{tabular}{|c|c|c|}
\hline & \multirow{2}{*}{$\begin{array}{c}\text { Value of parameter/wartość } \\
\text { parametru } \\
\text { vehicle } 3 / \text { pojazd } 3\end{array}$} \\
\hline \multicolumn{2}{|l|}{ Name of parameter/nazwa parametru } & \\
\hline Vehicle weight during calibration/masa samochodu w czasie kalibracji & $\mathrm{m}_{0}[\mathrm{~kg}]$ & 1480 \\
\hline Year of production/rok produkcji & & 2002 \\
\hline Wheel dynamic radius/promień dynamiczny koła & $\mathrm{r}_{\mathrm{d}}[\mathrm{mm}]$ & 305 \\
\hline Final drive ratio/przełożenie przekładni głównej & $\mathrm{i}_{\mathrm{g}}$ & 3.73 \\
\hline 1st gear ratio/przełożenie na biegu I & $\mathrm{i}_{\mathrm{bI}}$ & 3.91 \\
\hline Air resistance coefficient/wsp. oporu powietrza & $\mathrm{C}_{\mathrm{x}}$ & 0.32 \\
\hline Rolling resistance coef. (smooth asphalt)/wsp. oporu toczenia (gładki asfalt) & $f_{\text {to }}$ & 0.012 \\
\hline Power transmission system efficiency/sprawność ukt. przen. napędu & $\eta_{\mathrm{UPN}}$ & 0.92 \\
\hline
\end{tabular}

Table 3. Parameters of vehicle 3

Tabela 3. Parametry pojazdu 3 
of the city of Gdańsk (speed and elevation change profile). Verification was decided to be made with the use of computer simulation technique on account of a wide range of vehicle mass changes (1280-1780 kg, every $100 \mathrm{~kg}$ ) which would be technically difficult to realize in case of real vehicle. Moreover, verification of applied model correctness (9) with the use of computer simulation gives a possibility of using the same drive as a model of speed and elevation change profile at various mass. In road conditions exact performance of the same drive is impossible.

Figure 14 shows a characteristic family (9) created for the vehicle 3 during drive registered in real traffic conditions marked $1 \mathrm{v}$ (chosen parameters of the drive are in Table 4). Continuous lines mark relations $Q_{n}=f(\Phi)$ for various vehicle mass. Vehicle mass during calibration of relation (9) was $1480 \mathrm{~kg}$ and it was marked green in Figure 14.

Dashed lines in Fig. 14 mark characteristics (4) made with the use other registered vehicle marked $2 \mathrm{v}$ (chosen parameters of the drive are in Table 4) assuming for the purpose of simulation vehicle mass changing in the range $1280-1780 \mathrm{~kg}$. Fig. 14 allows to compare relations $Q_{n}=f(\Phi)$ obtained on the basis of model (9) calibrated at the mass 1480 $\mathrm{kg}$ and drive $1 \mathrm{v}$ (continuous lines) with relations obtained on the basis of model (4) calibrated at mass changing in the range $1280-1780 \mathrm{~kg}$ and drive $2 \mathrm{v}$ (dashed lines). On the basis of this comparison it may be concluded that the results obtained on the basis of model (9) distinguish themselves by high conformity with results obtained for individual drives with different mass. An average relative error of coefficient $\mathrm{k} 1$ representation (its value determines straight line inclination (4)) with the use of model (9) was $1.9 \%$ for 6 examined cases.

\begin{tabular}{|l|c|c|c|c|c|}
\hline Marking of the drive/oznaczenie trasy & $\overline{\mathrm{Q}}[\mathrm{J} /(\mathrm{m} \cdot \mathrm{kg})]$ & $\mathrm{L}_{\mathrm{n}} / \mathrm{L}$ & $\mathrm{t}_{\mathrm{bj}} / \mathrm{t}_{\mathrm{c}}$ & $\mathrm{L}[\mathrm{m}]$ & $\mathrm{t}_{\mathrm{c}}[\mathrm{s}]$ \\
\hline $1 \mathrm{v}$ & 0.62 & 0.68 & 0.23 & 10583 & 682 \\
\hline $2 \mathrm{v}$ & 0.69 & 0.64 & 0.31 & 7738 & 904 \\
\hline
\end{tabular}

użyciem techniki symulacji komputerowej ze względu na duży zakres zmian masy pojazdu (1280-1780 kg, co 100 $\mathrm{kg}$ ), co byłoby technicznie trudne do zrealizowania w rzeczywistym pojeździe. Ponadto weryfikacja poprawności użytego modelu (9) za pomocą symulacji komputerowej daje możliwość użycia tego samego przejazdu jako wzorca profilu prędkości i zmian wysokości przy różnych masach. W warunkach drogowych odtworzenie dokładnie takiego samego przejazdu nie jest możliwe.

$\mathrm{Na}$ rysunku 14 przedstawiono rodzinę charakterystyk (9) utworzonych dla pojazdu 3 przy przejeździe zarejestrowanym w warunkach rzeczywistego ruchu o oznaczeniu $1 \mathrm{v}$ (wybrane parametry przejazdu zamieszczono w tab. 4). Liniami ciągłymi zaznaczone zostały zależności $Q_{n}=f(\Phi)$ dla różnych mas pojazdu. Masa pojazdu, przy której wykonywana była kalibracja zależności (9) wynosiła $1480 \mathrm{~kg}$ i na rysunku 14 zaznaczona została kolorem zielonym.

Liniami przerywanymi na rysunku 14 zaznaczono natomiast charakterystyki (4) wykonane przy użyciu innego zarejestrowanego przejazdu o oznaczeniu 2v (wybrane parametry przejazdu zamieszczono w tab. 4) przyjmując $\mathrm{w}$ symulacji masy pojazdu zmieniające się w zakresie 1280 $1780 \mathrm{~kg}$. Na rys. 14 możemy porównać zależności $Q_{n}=\mathrm{f}(\Phi)$ uzyskane z modelu (9) skalibrowanego przy masie $1480 \mathrm{~kg}$

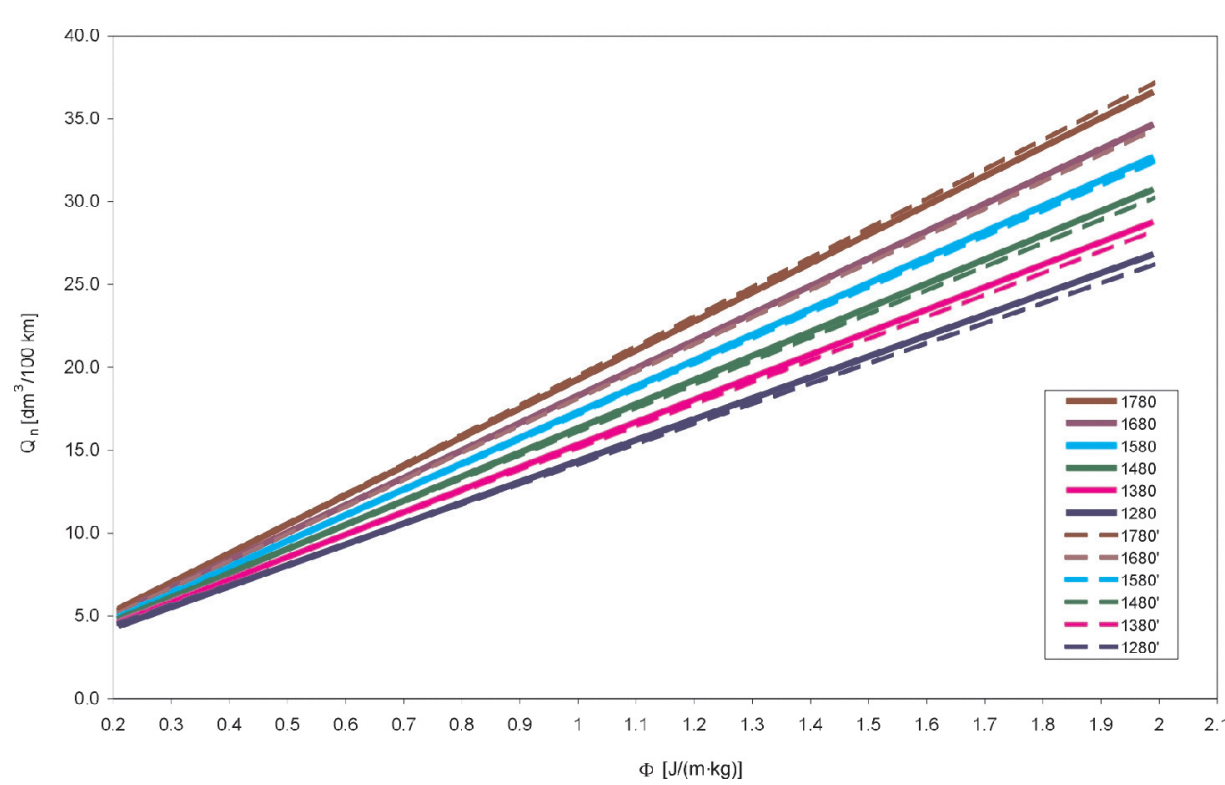

Fig. 14. Characteristic family (9) created for the vehicle 3 Rys. 14. Rodzina charakterystyk (9) utworzonych dla pojazdu 3 i przejeździe 1v (linie ciągłe) z zależnościami uzyskanymi z modelu (4) skalibrowanego przy masach zmieniających się w zakresie 1280-1780 kg i przejeździe 2v (linie przerywane). Na podstawie tego porównania można wnioskować, że wyniki uzyskane z modelu (9) odznaczają się wysoką zgodnością z wynikami uzyskanymi dla indywidualnych przejazdów przy różnych masach. Średni względny błąd odwzorowania współczynnika kierunkowego k1 (jego wartość decyduje o pochyleniu prostej (4)) przy użyciu modelu (9) wyniósł dla 6 przebadanych przypadków $1,9 \%$.

Dysponując zależnością (9) dla określonej masy $\mathrm{m}_{0}$ oraz opisem warunków eksploatacji w postaci funkcji (2) i parametrami: $\left(\mathrm{L}_{\mathrm{n}} / \mathrm{L}\right),\left(\mathrm{t}_{\mathrm{bj}} / \mathrm{t}_{\mathrm{c}}\right), \mathrm{L}, \mathrm{t}_{\mathrm{c}}$, jak również aktualną masą pojazdu (1500 kg) powtórzono obliczenia przebiegowego zużycia paliwa dla czterech wybranych tras przejazdu samochodem. Zesta- 
Having relation (9) for specified mass $\mathrm{m} 0$ as well as a description of operation conditions in a form of function (2) and parameters: $\left(\mathrm{L}_{\mathrm{n}} / \mathrm{L}\right),\left(\mathrm{t}_{\mathrm{bj}} / \mathrm{t}_{\mathrm{c}}\right), \mathrm{L}, \mathrm{t}_{\mathrm{c}}$ and current vehicle mass $(1500 \mathrm{~kg})$ calculations of operational fuel consumption for four chosen travel routes were repeated. The results for two test vehicles are listed in Table 5 .

Comparison of reference fuel consumption for operation conditions met on chosen routes shows that more economical wienie wyników dla dwóch pojazdów testowych przedstawiono w tabeli 5 .

Z porównania referencyjnego zużycia paliwa dla warunków eksploatacji spotykanych na wybranych trasach wynika, że bardziej ekonomicznym jest pojazd 1, który potencjalnie będzie zużywał mniej paliwa we wszystkich analizowanych przypadkach. Podobnie jak w pierwszej analizie (tab. 3) przy pogarszaniu warunków ruchu (wzrost $\bar{\Phi}$ ) względna różnica

Table 5. Comparison of operational fuel consumption of test vehicles of the same mass during operation on chosen routes

Tabela 5. Porównanie przebiegowego zużycia paliwa pojazdów testowych o tych samych masach przy eksploatacji na wybranych trasach

\begin{tabular}{|c|c|c|c|c|c|c|c|c|c|}
\hline \multirow{3}{*}{$\begin{array}{l}\text { Route No./ } \\
\text { nr trasy }\end{array}$} & \multirow{3}{*}{$\begin{array}{l}\text { Location/ } \\
\text { lokalizacja }\end{array}$} & \multirow{3}{*}{$\begin{array}{c}\bar{\Phi} \\
{[\mathrm{J} /(\mathrm{m} \cdot \mathrm{kg})]}\end{array}$} & \multirow{3}{*}{$\mathrm{L}_{\mathrm{n}} / \mathrm{L}$} & \multirow{3}{*}{$\mathrm{t}_{\mathrm{bjj}} / \mathrm{t}_{\mathrm{c}}$} & \multirow{3}{*}{$\mathrm{L}[\mathrm{m}]$} & \multirow{3}{*}{$\mathrm{t}_{\mathrm{c}}[\mathrm{s}]$} & \multicolumn{2}{|c|}{$\overline{\mathrm{Q}}\left[\mathrm{dm}^{3} / 100 \mathrm{~km}\right]$} & \multirow{2}{*}{$\frac{\overline{\mathrm{Q}_{2}}-\overline{\mathrm{Q}}_{1}}{\overline{\mathrm{Q}}_{1}}$} \\
\hline & & & & & & & $\begin{array}{l}\text { vehicle } 1 / \\
\text { pojazd } 1\end{array}$ & $\begin{array}{l}\text { vehicle 2/ } \\
\text { pojazd } 2\end{array}$ & \\
\hline & & & & & & & $1500 \mathrm{~kg}$ & $1500 \mathrm{~kg}$ & {$[\%]$} \\
\hline 1 & $\begin{array}{l}\text { outskirts/ } \\
\text { przedmie- } \\
\text { ścia }\end{array}$ & 0.48 & 0.73 & 0.26 & 11786 & 784 & 6.5 & 6.9 & 6 \\
\hline 2 & $\begin{array}{l}\text { centre/ } \\
\text { centrum }\end{array}$ & 0.73 & 0.57 & 0.44 & 10937 & 1145 & 7.34 & 8.41 & 15 \\
\hline 3 & $\begin{array}{l}\text { centre/ } \\
\text { centrum }\end{array}$ & 0.82 & 0.54 & 0.53 & 5168 & 625 & 7.88 & 9.24 & 17 \\
\hline 4 & $\begin{array}{l}\text { centre/ } \\
\text { centrum }\end{array}$ & 1.54 & 0.42 & 0.38 & 6245 & 612 & 9.57 & 11.37 & 19 \\
\hline
\end{tabular}

vehicle is vehicle 1 which will consume potentially less fuel in all analyzed cases. Like in the previous analysis (Tab. 3) in case of deteriorating traffic conditions (rise of $\bar{\Phi}$ ) relative difference of fuel consumption is steadily growing. In case of the lightest operation conditions (route No. 1) this difference is $6 \%$, and in case of the most difficult operation conditions (route No. 4) this difference reaches 19\%. On account of the fact that reference fuel consumption was calculated at the same mass of vehicles 1 and 2 it may be concluded that vehicle 1 has more efficient drive system.

\section{Conclusions}

Presented method enables to determine reference fuel consumption for registered operation conditions. Operation conditions are described by distribution of parameter $\Phi$ (it takes into account both an influence of external conditions and a style of driving a car by a driver) and by the following parameters: share of propulsion phase $\left(\mathrm{L}_{\mathrm{n}} / \mathrm{L}\right)$ share of work at idle speed $\left(\mathrm{t}_{\mathrm{bj}} / \mathrm{t}_{\mathrm{c}}\right)$. Reference fuel consumption calculated with the use of this method may be compared with registered operational fuel consumption. For example, having the results of such an analysis it may be explicitly determined whether an increase of operational fuel consumption is justified by worse traffic conditions. When the measured operational fuel consumption is considerably higher than the reference fuel consumption two situations should be considered: 1 . the driver realized improper style of drive system control (e.g. driving with small load and high engine speed), 2. drive system was damaged.

Preparation of fuel consumption characteristic $Q_{n}=f(\Phi)$ proposed in this paper by car dealers (one drive in urban zużycia paliwa sukcesywnie wzrasta. Przy najlżejszych warunkach eksploatacji (trasa nr 1) różnica ta wynosi $6 \%$, a przy najtrudniejszych warunkach eksploatacji (trasa nr 4) różnica ta dochodzi do $19 \%$. Ze względu na to, że referencyjne zużycie paliwa zostało obliczone przy tej samej masie pojazdów 1 i 2 można wnioskować, że pojazd 1 ma bardziej efektywny układ napędowy.

\section{Wnioski}

Przedstawiona metoda umożliwia wyznaczenie referencyjnego zużycia paliwa dla zarejestrowanych warunków eksploatacji. Warunki eksploatacji opisane są rozkładem parametru $\Phi$ (obejmuje zarówno wpływ warunków zewnętrznych jak również styl jazdy kierowcy) oraz parametrami: udział fazy napędowej $\left(\mathrm{L}_{\mathrm{n}} / \mathrm{L}\right)$ i udział pracy na biegu jałowym $\left(\mathrm{t}_{\mathrm{bj}} /\right.$ $\mathrm{t}_{\mathrm{c}}$ ). Obliczone tą drogą referencyjne zużycie paliwa można porównać $\mathrm{z}$ zarejestrowanym, eksploatacyjnym zużyciem paliwa. Przykładowo dysponując wynikami takiej analizy można jednoznacznie stwierdzić czy wzrost eksploatacyjnego zużycia paliwa jest uzasadniony gorszymi warunkami ruchu. W przypadku, gdy zmierzone, eksploatacyjne zużycie paliwa jest znacząco większe niż referencyjne zużycie paliwa należy rozważyć dwie sytuacje: 1. kierowca przyjął niepoprawny sposób sterowania układem napędowym (np. jazda przy małym obciążeniu i jednocześnie wysokiej prędkości obrotowej silnika), 2. uszkodzony został układ napędowy.

Przygotowanie przez firmy sprzedające samochody zaproponowanej w pracy charakterystyki zużycia paliwa $\mathrm{Q}_{\mathrm{n}}=\mathrm{f}(\Phi)$ (jeden przejazd $\mathrm{w}$ warunkach ruchu miejskiego $\mathrm{z}$ rejestracją podstawowych parametrów pracy silnika i pojazdu) pozwoliłoby porównywać efektywność energetyczną 
cycle with registration of basic engine work and vehicle parameters) would enable to compare energy efficiency of various vehicles drive systems. It would take place in more reliable way than it happens today, i.e. comparison of fuel consumption in conditions of a chosen certification test. Generally, a vehicle with more efficient drive system would have $\mathrm{Q}_{\mathrm{n}}=\mathrm{f}(\Phi)$ characteristic located lower. Having additionally a map of operation conditions (described by parameter $\Phi$ distribution) for a chosen agglomeration or travel route, fuel consumed by a given vehicle may be forecasted. For example, a person who is going to buy a car may compare various cars in respect of fuel consumption depending on the style of car operation specific for this person. układów napędowych różnych pojazdów. Odbywałoby się to w sposób bardziej miarodajny niż jest to czynione obecnie - porównywanie zużycia paliwa osiągniętego $\mathrm{w}$ warunkach wybranego testu homologacyjnego. W ogólnym przypadku pojazd o bardziej efektywnym układzie napędowym będzie posiadał niżej położoną charakterystykę $Q_{n}=f(\Phi)$. Dysponując dodatkowo mapą warunków eksploatacji (określonych rozkładem parametru $\Phi$ ) dla wybranej aglomeracji lub trasy przejazdu można prognozować zużycie paliwa wybranego pojazdu. Przykładowo, ktoś decydując się na zakup samochodu może przeprowadzić porównanie różnych egzemplarzy ze względu na ilość zużywanego paliwa przy sposobie eksploatacji właściwym dla niego jako kierowcy.

\section{Bibliography/Literatura}

[1] Casey E.J., Smith W.J., Timoney D.J.: Examination of Lowcost Systems for the Determination of Kinematic Driving Cycles and Engine Operating Conditions in Dublin, Ireland. SAE 2009 Powertrains Fuels and Lubricants Meeting, November 2009, San Antonio, TX, USA, Session: On-Board Diagnostics. SAE 2009, 2009-01-2791.

[2] Cayot J. F.: Compared fuel consumption between gasoline and diesel cars during short urban drive. Reducing automobile fuel consumption: a challenge for the turn of the century, RueilMalmaison, 4 X 1996.

[3] Chłopek Z.: Modelowanie procesów emisji spalin w warunkach eksploatacji trakcyjnej silników spalinowych. Oficyna Wydawnicza Politechnik Warszawskiej, Warszawa 1999.

[4] Cichy M., Kropiwnicki J., Makowski S.: Model silnika spalinowego w formie grafów wiązań $(\mathrm{GW})$. A model of the IC engine in the form of the bond graph (BG). Silniki Spalinowe - Combustion Engines, 2004 s. 40-47.

[5] Cichy M.: Modelowanie systemów energetycznych. Wydawnictwo Politechniki Gdańskiej, Gdańsk 2001.

[6] Combe T., Kollreider A., Riel A., Schyr Ch.: Modellabbildung des Antriebsstrangs-Echtzeitsimulation der Fahrzeuglaengsdynamik. MTZ 1/2005, s. 50-59.

[7] Kretzsch M., Günther M., Elsner N., Zwahr S.: Modellansätze für die virtuelle Applikation von Motorsteuergeräten. MTZ 09/2009: 665-670.

[8] Kropiwnicki J.: Influence of traffic conditions on the operating fuel consumption. Developments in Mechanical Engineering, Gdańsk University of Technology Publishers, Gdańsk 2009, Volume 3.

[9] Kropiwnicki J.: Koncepcja nowego testu energetycznego dla pojazdów samochodowych. Archiwum Motoryzacji. 2007, nr 2, s. 169-183.

[10] Kropiwnicki J.: Możliwości parametrycznej identyfikacji warunków eksploatacji pojazdu samochodowego. Journal of KONES: Powertrain and Transport. Vol. 15, nr 4 (2008), s. 289-296.
[11] Kulkarni A. V., Sapre R. R., Sonchal Ch. P.: Gps-Based Methodology for Drive Cycle Determination. SAE 2005 World Congress \& Exhibition, April 2005, Detroit, MI, USA, Session: Testing and Instrumentation (Part $1 \&$ 2). SAE 2005, 200501-1060.

[12] Leung D. Y. C., Williams D. J.: Modelling of motor vehicle fuel consumption and emissions using a power-based model. Environmental Monitoring and Assessment 65: 21-29, 2000.

[13] Merkisz J.: Ekologiczne problemy silników spalinowych. Wydawnictwo Politechniki Poznańskiej, Poznań 1998.

[14] Romaniszyn K.M.: Ocena różnic w określaniu zużycia paliwa samochodu na podstawie charakterystyki uniwersalnej i dynamicznej. Silniki Spalinowe 2/2004 (119): 48-54.

[15] Siłka W.: Teoria ruchu samochodu. WNT, Warszawa 2002.

[16] Tzirakis E., Pitsas K., Zannikos F., Stournas S.: Vehicle emissions and driving cycles: comparison of the athens driving cycle (ADC) with ECE-15 and european driving cycle (EDC). Global NEST Journal, Vol 8, No 3: 282-290, 2006.

[17] Ubysz A.: Energochłonność samochodu a zużycie paliwa w złożonych warunkach ruchu. Wydawnictwo Politechniki Śląskiej, Gliwice 2003.

[18] Wang Yunlong, Li Xiansheng, Cai Fengtian, Guan Yuzhe, Li Shiwu: Fuel Consumption Model for Passenger Vehicle in China. FISITA 2008 World Automotive Congress. F200810-029.

Mr Jacek Kropiwnicki, DEng. - doctor in the Faculty of Mechanical Engineering at Gdańsk University of Technology.

Dr inż. Jacek Kropiwnicki - adiunkt na Wydziale Mechanicznym Politechniki Gdańskiej. e-mail: jkropiwn@sunrise.pg.gda.pl

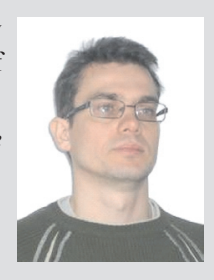

